\title{
Professional translation competence in advanced training process
}

\author{
Elena Meshcheryakova ${ }^{1, *}$ and Julia Meshcheryakova ${ }^{1}$ \\ ${ }^{1}$ Volgograd State Socio-Pedagogical University, 27, Lenina av., 400005, Volgograd, Russia
}

\begin{abstract}
The authors regard the technology for the translating competence improving within the training framework at the Institute of Foreign Languages. This article analyzes the basics for creating an online teaching course in order to progress translating skills seeing those as general professional training elements. The authors give a detailed overview of main translating professional competences, including their structure and classification, the ones needed to be improved in the professional development process. The system development aspects of translation competence enhancement are specified. The content and structure of appropriate translation skills and the abilities development program are considered. The authors analyzed a variety of skills technologies for developing translating skills. Professionally oriented translation skills are detailed as the translator development program components. The exercise typology used in teaching translation is considered. Some types of sample exercises for practical translation skills laboratory classes are given.
\end{abstract}

\section{Introduction}

According to modern training programs, all specialists have competencies formed at a level sufficient for their professional success [1]; [2]. However, in their implementation process, almost all specialists are facing cases, not included into programs, as the real social and cultural environment is changing very quickly. To solve this problem, there are professional development courses, including for the translators.

At the present time the staff professional development system is quite developed in Russia and abroad, but over time it has required improvement, as the society is undergoing continuous changes. Respectively, the requirements for specialist qualification are also constantly changing. These changes greatly affect the translation staff - there are new terms, concepts, phenomena in the social and cultural environment that require new knowledge and new vocabulary.

The purpose of this article is to consider the technology to improve professional translation competences at the Institute of Foreign Languages, Additional Education Institute and Advanced Training Faculty at Volgograd State Socio-pedagogical University. Every year about 10 specialists leave these schools under the program "Translator in the field of professional communication" and about 20 specialists under program 45.03.02 "Linguistics". Also, these institutions train bachelors in "Translation and theory of Translation" (first foreign language - English, second foreign language - German/French/Chinese). However, as experience shows, this is not enough, so there are courses and training programs for translators, which can be online either partially or completely.

\section{Materials and methods}

Translation competence is the leading one for these specialists. According to the translator training structure program it is considered an integral part of the general professional competence and requires constant development and improvement.

For this purpose, the higher professional education system has a good scientific, psychological and pedagogical base. Many researchers have analyzed various aspects of the effective education content organization and process in the translator training (I. S. Alekseeva [3], V. N. Commissarov [4], L.K. Latyshev [5], L. Behiels [6], M. M. Martin, A. M. Ruguera [7]). Professional translation competence is the subject of discussion for the following scientists: L. I. Borisova [8], M. P. Brandes [9], V. S. Vinogradov [10], V. G. Gak [11], R. K. Minyar-Beloruchev [12], V. V. Sdobnikov [13], I. I. Khaleeva [14], A. D. Schweitzer [15] L. Koordic [16], S. Trujillo [17], A. G. Cano [18] and others. Theoretical bases for constructing an expert model are stated in the works of E. E. Smirnova [19], N. F. Talyzina [20], V. D. Shadrikov [21]. Moreover, I. V. Kochergin [22] and Yu. A. Tsitselskaya [23] developed the models of an intercultural communication specialist.

For translator training and development, scientists concern different components in translation and professional competence, for example, socio-cultural competence (E. N. Malyuga, A. Krouglov, B. Tomalin [24]), as well as linguistic, discursive, strategic, social,

\footnotetext{
Corresponding author: elenam7@yandex.ru
} 
and etc. Basic components of translation competence usually include knowledge, skills necessary for all translation types.

The translation competence creation is aimed at a rather peculiar linguistic personality. It manifests itself in such speech communication aspects as 1) language, 2) communicative, 3) personal and 4) profession oriented aspects.

In view of the fact that any translator is obliged to use many activities, implying various communication forms in foreign and native languages, the professional translator development and their retraining have their own characteristics. It is necessary to organize training in a number of translation types, which can only occur with the specific methodological techniques and technologies. A professional translator traditionally specializes in one or more translation types.

The language competence of a professional translator also includes all language proficiency aspects specific to any native speaker, hearing and cognitive skills, and lexical and grammatical competences. In addition, the language competence includes specific features due to the fact that "the translator must keep in his memory certain knowledge: language system knowledge, its grammatical and dictionary structure, certain sets of language units in various communication fields, the language rules for speech construction" [5].

An important factor is the fact that the professional translator specifics are the need for language competence at a proper level within two languages at least.

The translator language competence has its limits, but the wider they are, the higher the general professional competence level is. The translation activities, like any other professional activity, call for continuous improvement of knowledge, skills and abilities in the relevant fields.

Effective construction of replicas in any foreign language communication requires from a professional translator creative text building skills according to the accepted rules and stereotypes in this socio-cultural environment. The translation competence includes the knowledge of both languages rules and the ability to build texts of different types, to interact in a diverse communication [25].

It is very important for a translator to have the communication competence present in two languages at the same time. Without it, translation activity is impossible. The professional competence of a translator involves the ability to interpret the statement and text meaning, and also includes the ability to project individual features of translation receptors within original statements. If necessary, a translator should be able to adjust the ratio of the language content and the output meaning. In this case, missing background information is in the statement itself or in the corresponding explanations [12].

The professional competence of a translator is certain to include the technical competence. This is the specific knowledge, skills and abilities that are necessary to perform the translation in the particular field.

For the professional interpreting technique special skills are also of great importance. The most significant translation skills are the following [26]: the ability to perform actions in several languages, to switch from Russian into English and from English into Russian; the ability to understand how deep a certain expression is, which is inherent in the translation languages; the ability to perform simultaneous actions in two languages in the translation process, the ability to answer questions "what does this phrase mean?" or "what did the author want to say?"; the ability to choose the closest match to the original. In communication the important and necessary methods are adequate perception of delays in the replicas exchange, silence periods in communication and pauses [27].

The translators training and retraining processes are based on a variety of strategies and technologies (R. S. Robert, L. Brunette [28], L. Bihiels [6], N. M. Martin, A.M. Reguerra [7]), including information communication technologies (S. Piccioni, G. Pontrandolfo [29]), professional translation competence level (M. L. Perrasi, A. F. Centerno [30]).

A sample program of translation professional development says that trainees should improve the following professionally oriented skills and abilities:

- the skill to use explanatory and bilingual dictionaries, reference books, to solve translation problems;

- the skill to use translation transformations, language and contextual transformations;

- the ability to carry out a full and abstract translation in writing;

- the ability to edit a native language text.

\section{Results and discussion}

At the present stage, the important problem of the translation professional development system is aimed at the solution of the following tasks:

- to select and to organize the material for the improvement of the translation competency, taking into account the translation types, texts genres for translation, translation transformations faced by students at work in their institution, company, etc.;

- to improve the translation competence and its all components;

- to create a set of tasks to improve the translation competence.

The main aspects of the translation competence improvement are:

- methodological - translation competence structure;

- translation studies - classification of translation types, translation transformations;

- linguistic - genres necessary for a more successful professional activity.

The genre classification studied in the professional translator training is considered as a linguistic aspect of teaching translation. In accordance with the requirements of any sample program and Federal Academic Standard, trainees should develop skills to discern and translate texts of such genres as a literary text, an advertising text, a newspaper article, an encyclopedia article [31] to be 
able to carry out verbal interaction in a variety of tasks and communication [32].

According to the sample program for literature studies, students acquire these skills in Literature class, so at the pre-translation stage the complex translation tasks suggest determining any text genre, focusing on these skills.

The translation aspect takes into account the teaching translation material, which stands out by its translation text presentation and original text. However, for translation learning, one has to make the translation transformation that should be taught to language graduates.

According to the translation professional development program, trainees should improve the following translation techniques: replacement, addition, omission, calque, rearrangement.

We strongly recommend for the students to fulfil the following assignments as the translation transformation tasks:

- read and analyze the changes in the texts;

- emphasize the omission or addition in the examples;

- use one or another type of translation transformations when doing the translating.

The authors of the article share V. N. Komissarov's point of view that the learning translation process, and in our case, the process of improving the ability to translate, should be aimed at a full understanding of the source text, internal speech creation and making a creative real text, fully adequate to the original version proposed by the listener [4]. However, social and cultural situation changes, understanding of what to teach changes as well. In the first place they put the improving the professional competence of a translator and, surely, competencies that are components of this professional competence.

At the end of professional development course, the translation competence content will include translation and foreign language communication competence. At the same time, language competence will include not only grammar, vocabulary as a linguistic competence, but also a continuous development of this knowledge. It can also include strategic competence, which allows the translator to look for strategies to compensate for language gaps.

The communicative competence will be correlated with sociolinguistic competence, as these competencies are aimed at using and transferring social and cultural information. Sociolinguistic and technical competencies combine the ability to determine and choose language forms according to the situation, context and translation type, which correlates these types with each other. Finally, the text-forming competence is close to discursive one due to different types of transferring, understanding, forming and creating diverse messages and texts for information transmission.

It is clear that translation competence includes a foreign language communication competence. To master translation competence, it is necessary to master all its components - linguistic, discursive, social and cultural, strategic and social competence.
It is assumed that in addition to its own components, the following competencies are included in translation competence: language, technical, speech, discursive, compensatory, strategic, text-forming, personal and general educational. The mentioned components of translation competence will be formed at translation and general subject classes.

Our latest upgraded training program "Translation and translation studies" offers a number of sections aimed at improving the general professional competence and translation competencies discussed in this article. The first section is mainly about modern approaches to solving the translation adequacy problem, improving strategies to implement the social order in the translating process from Russian into English and back, developing skills for meaningful information transfer, etc.

The second section is even more enthralling for trainees because it is even more specific. During learning, students consider appropriate translation strategies in different situations, study translation techniques in relation to language levels and transformation possibility. The attention is focused on the message essence and Russian and English text style, as well as grammatical structure translation.

The last section, which is extremely popular (as our practice shows), requires constant alteration due to more modern terms. It is "Visual-written translation and visual-oral translation of a foreign text." Sporadically, professors update the materials for the "Modern peculiarities of newspaper texts translation and informational (articles, short and extended messages, expositions and headers)". They work with trainees on preserving the fact, logic and documentation in the translation. Improving synchronization skills, the ability to select suitable equivalents in interpretative translation, as well as the text advanced reading development, educational descriptive translation training are becoming increasingly significant.

The teachers' work is aimed at training the skills to use correct grammatical structures, assistance in choosing the right style, correct vocabulary, the ability to use the libraries and reference books, documents of relevant companies and online resources.

The students hand in the material in diverse ways. In recent years, to submit it on the Google platform is more welcome, which contributes to translation skills development and team skills projects and rapid review and feedback by the teacher. Undoubtedly, digital technologies contribute to more efficient and highquality projects by the course students.

In the class exercises are the main way to work out the necessary translation skills. Usually, when translating any kind of text, a translator faces a number of specific tasks; therefore, the solution of such tasks requires an integrated approach. We present the exercise typology, which we find the most effective. The first group before translating - is dedicated to the difficult moments in translation and the choice of the necessary methods and strategies. The second group - while translating - is aimed at the quick reactions and the translation abilities. And the third, the last group of exercises - after translating - helps to improve the translation already 
done by the students, to correct ready texts taking into account synonyms, the differentiation of content, periphrases, interpretation and etc.

A significant number of purely translation and operational exercises aimed at comparing specific phenomena in the Russian and English languages, the communication strategies and specific translation techniques are also used [4].

Communication tasks are aimed at training to interpret the message meaning under varying complexity. For example, at this stage, translators analyze the level of translation equivalence of a certain text genre (in our case we often use a joke as an example for a better understanding) and the choice of the correct translation transformation. Then they make an attempt to interpret the context, the purpose of which is to identify the basic facts about the text content for a more accurate translation and the true meaning transfer:

- What do you call a blind dinosaur?

- "Do-you-think-he-saurus".

- What do you call a blind dinosaur's dog?

- You got me.

- Ah,"Do-you-think-he-saurus' Rex".

- Как Вы назвали слепого динозавра?

- Я не знаю, какого слепого динозавра? Слепозавр?

- Как вы назовете собаку слепого динозавра?

- Помоги мне!

- Слепозавр Рекс.

Here is another noteworthy example from practical exercises. It is expected that translators give the reasoning, solve translation difficulties in the task, provide links to dictionaries and other documents where there is information about the meaning:

Вечно острая стоящая проблема - наши отношения с людьми. Возьмем, к примеру, собаку, существо, полностью зависящее от человека и не имеющее личных интересов. Собака будет следовать за хозяином буквально по пятам. В качестве более высоко организованного существа, мы, как это говорится, живем сами по себе. Да, мы полностью независимь от капризов человека, $a$, равно как и от его желания нас контролировать $u$ m. $\partial$.

When exercising, a young translator is obliged to solve a number of side tasks in addition to the main ones, which he or she needs to discuss with the teacher. Basically, such tasks are, for example, the following situations: the translator must adhere to the peculiarities of the language associated with the text use.

According to the generally accepted modern standard, the exercise includes about 10 sentences, including a variety of translation difficulties, not coloured stylistic phrases, taken from unrelated texts.

For example,

1. Никто ничего не мог сказать. 2. Кто-то взял мой зонтик и оставил свой. 3. Вам требуется моя помощь? 4. Не могли бы мы увидеться в воскресенье? 5. Лето, несомненно, одно из лучших времен года.

It's no secret that to translate expressions taken out of context causes great difficulties for understanding and translating. Such difficulties can be overcome in different ways:

First, the trainer should choose expressions that do not require context or make a number of sentences that form the text. Secondly, the teacher must be constantly ready to provide the participants of the upgraded course with additional information that will eliminate the meaning ambiguity. Third, as one of the leading strategies, we can discuss understanding and translation options that are correct in various linguistic and situational contexts.

As a result of the five year work experience for the study course described in this article, the most effective strategies for improving the translation competence are recognized as the following.

"Indicating translator's false friends". The term "translator's false friends" implies phonetic similarity of lexemes in two or more languages, in other words, interlingual paronyms. Such words are similar in spelling or pronunciation, but differ in the meaning. For example, actual and актуальный, сотровеr and композитор, genial and гениальный. The stainees are encouraged to identify translator's false friends to establish semantic links within a single text. This technique works both in a group and individual work in the classroom, which implies both team and individual activities. According to the proposed list of paronyms, trainees read aloud sentences in the target language. When in a group the students discuss and comment on the use of translator's false friends. If individual, then the task should be done in writing.

"Challenge" (or "Translators are rivals"). This type of work is the most engaging and popular among students. It has competitive and complex nature, and consists of several tasks. The purpose of each task is the translation adequacy in the studied language pair, and it also regulates how to use translation transformations in the translation process. The trainees are asked to translate one compound sentence and to use the already wellknown translation techniques, methods and tactics. The translation performed at all equivalence levels is rewarded.

"Reverse translation." This type of work is used in the class during the initial cycle of the translation techniques study. It is advisable to use it to increase motivation /interest in the translation tactics study. An important fact is that the team work reveals an extraordinary solution for typical translation tasks, which contributes to a sharp interest increase in translation activities. On the board/screen a trainer demonstrates the receptor language text; this text is from the work of art belonging to the native culture and known to all students. The trainees are given a task: to name the source, quote the original and discuss/correct the used translation transformations. Questions and suggestions that arise in the translation and discussion processes can be used as a starting point for the next lesson.

«Championship». It is the final stage when testing the acquired translation skills. In this lesson, students are to use digital translation technologies, namely to compare and analyze machine translation performed by several different mobile and web services open to public access 
and use. Within the task, it is necessary to perform the following actions in advance and independently:

- after fulfilling the same text translation, carried out by different services, to do the description and come to the conclusion about the specifics and statistics of interlanguage correspondences, types of equivalents, different types of translation transformations,

- as the final stage - to act as an editor and perform post-editing of any translation options based on the source text.

«Teamwork». Text translation is carried out by a group of trainees sitting one-by-one in a circle. Each learner translates his/her sentence when it is his or her turn. The rest listen to, evaluate, and suggest what techniques are best used in a particular case. This technique improves rapid response skills, switching attention, teamwork skills, which can be very useful in their future professional work. Especially it is necessary to focus on the memory training - the vocabulary and structures already used, and the substitutes which have not been used yet.

These strategies have been employed in the professional translation development courses and they depend on the existing competence levels. At the initial stage, there are used more simple ones aimed at improving the language knowledge; "Indicator of translator's false friends" and "Reverse translation" - to increase the motivation for the courses. At the middle stage, the preference is given to "Challenge", because this strategy requires a greater set of knowledge, skills and abilities. At the advanced stage, "Team work" and "Championship" are used more often, they help to improve the professional competence in a variety of situations and to assess the translation level the trainees reach at the courses.

\section{Conclusion}

In conclusion, we can note that the advanced training course program comprises all the necessary sections and tasks for improving the necessary translation competencies, knowledge, skills and translation activities. The translation competence includes not only all language proficiency aspects that characterize any native speaker, but also a number of specific features. It is established that to acquire the ability to create various texts, corresponding to all language laws, requires a successful exchange of speech works. The main competencies are communication and professional. Without them, the translator's path cannot be productive. The basic principle of a professional translation strategy is to use all abilities to create the best translation option. The strategy of a successful professional in translation activity depends on the translation target and the implementation conditions; therefore it provides the task be performed more effectively.

Thus, the improving translation competence technology has been carefully analyzed and the most necessary aspects have been chosen. The program for professional translation development should be selected so that each graduate improves standard translation techniques and acquires new translation strategies and tactics.

The set of tasks and exercises should be designed in such a way that translators who progress their professional qualities, first, master the subject area in the language environment and terminology, and secondly, in a practical way improve and develop their skills and abilities for their understanding or consolidation and further successful use in all professional activities.

The proposed technologies described in this article also effectively confirm the training program created by us and becoming increasingly popular and successful work of students in their companies and institutions after training.

\section{References}

1. T.P. Kostyukova, I.A. Lysenko, V.S. Saubanov, Concentration of resources of advanced training courses in innovative areas of development, Scientific support of the system of advanced training 1 (34) 36-43 (2018)

2. E.A. Loktyushina, About change of requirements to professional readiness of teachers of foreign, Scientific providing of system of professional development of shots 2 (15) 12-17 (2013)

3. I.S. Alekseeva, Introduction to translation studies introduction (Publishing center "Academia", Moscow, 2004)

4. V.N. Comissarov, Modern translation studies (ETS, Moscow, 2012)

5. L.K. Latyshev, Translation Technology (Publishing center "Academia", Moscow, 2014)

6. L Behiels, Hermeneus, 20 11-35 (2018)

7. M.M. Martin, A.M. Ruguera, MonTI 8 225-255 (2016)

8. L.I. Borisova, Lexical features of English-Russian scientific and technical translation (Moscow, 2005)

9. M.P. Brandes, Pre-translation text analysis (Moscow, 2001)

10. V.S. Vinogradov Introduction to Translation Studies (Prosveschenie, Moscow, 2001)

11. V.G. Gak Translation Course (Nauka, Moscow, 1962)

12. R.K. Minyar-Beloruchev, General translation theory and oral translation (Moscow, 2015)

13. V.V. Sdobnikov, Translation theory (Moscow, 2007)

14. I.I. Khaleeva, Introduction to foreign speech understanding teaching (Visshaya Shkola, Moscow, 1989)

15. A.D. Shveitser, Translation theory (Nauka, Moscow, 1988)

16. L. Koordic, Studies in logic, grammar and rhetoric 45 (58) 97-109 (2016)

17. S. Trujillo, MonTI 8 257-278 (2016)

18. A.G. Cano, Hermeneus, 20 165-211 (2018) 
19. E.E. Smirnova, Ways of forming a model of a higher education specialist (Leningrad University Publishing, Leningrad, 1977)

20. N.F. Talyzina, Specialist model theory development (Znanie, Moscow, 1986)

21. V.D. Shadrikov, Systemogenesis of professional and educational activity (Russian Science Academy Publishing, Moscow, 2017)

22. I.V. Kochergin, Chinese linguistic didactics (ACT, Moscow, 2006)

23. Yu.A. Tsitselskaya, The role of students' self-control in foreign language teaching (Saint-Petersburg, 2002)

24. E. N. Malyuga, A. Krouglov, B. Tomalin, XLinguae, 2 (11) 566-582 2018

25. E.V. Meshcheryakova, The problem of pedagogical interaction in the educational space when teaching foreign languages (Volgograd State Pedagogical University, Volgograd, 2002)

26. Y.I. Retsker, Translation practice and theory (Mezhdunarodnie otnosheniya, Moscow, 2011)
27. T.J. Bruneu, Communicative Silence: Forms and Functions The Journal of Communication 23 17-46 (1973)

28. I.S. Robert, L. Brunette, Should revision trainees think aloud while revising somebody else's translation? Meta 61 (2) 320-345 (2016)

29. S. Piccioni, G. Pontrandolfo, Translation competence and ICT 12 87-101 (2017)

30. M.L. Perrasi, A.F. Centerno, Towards training in specialized translation: facts and challenges Íkala, Revista de Lenguaje y Cultura, 21(1) 49-61 (2016), URL:

http://aprendeenlinea.udea.edu.co/revistas/index.php /ikala/article/view/20479 (date of access 20.04.2019)

31. V.S. Slepovich, Translation Course (TetraSystems, Minsk, 2015)

32. E.V. Meshcheryakova, V.K. Andreyeva, Advanced English Manual (Volgograd-Moscow, 2003) 